\title{
PENGARUH METODE PROBLEM SOLVING TERHADAP KEMAMPUAN PEMECAHAN MASALAH SISWA PADA MATA PELAJARAN EKONOMI MATERI PAJAK
}

\author{
Citra Anggreini*1, Eeng Ahman ${ }^{2}$, Ikaputera Waspada ${ }^{3}$ \\ Sekolah Pascasarjana, UPI Bandung ${ }^{1,2,3}$ \\ citra.ang95@upi.edu, eengahman@upi.edu;ikaputerawaspada@upi.edu
}

\begin{abstract}
ABSTRAK
Metode pembelajaran yang tepat digunakan pada kelas akan menimbulkan semangat belajar siswa. Siswa tidak akan merasa bosan dan siswapun dapat dilatih untuk berfikir kreatif. Penelitian ini bertujuan mengetahui seberapa besar pengaruh kemampuan pemecahan masalah siswa pada mata pelajaran ekonomi materi pajak dengan menggunakan metode problem solving. Penelitian ini dilakukan di SMAN 1 Ciwidey Kabupaten Bandung. Subjek dari penelitian ini adalah siswa kelas XI jurusan Ilmu Pengetahuan Sosial (IPS) yaitu XI IPS 1 dengan jumlah 34 siswa. Metode yang akan digunakan dalam penelitian ini adalah eksperimen semu (quasi eksperimen) untuk mengetahui efek perlakuan (treatment). Teknik analisis data menggunakan uji validitas dan reliabilitas, uji normalitas dan uji hipotesis. Hasil penelitian dapat disimpulkan Kriteria pengujiannya adalah jika Sig. (Signifikansi) atau nilai probabilitas < 0,05 maka distribusi adalah tidak normal, sedangkan jika nilai signifikansi atau nilai probabilitas > 0,05 maka distribusi adalah normal. Dalam kemampuan pemecahan masalah siswa menggunakan metode problem solving memperoleh nilai rata-rata 79 sebelum perlakuan nilai rata-rata dineroleh 27 dengan nilai KKM 70. Pada ketentusan indikator kemampuan pemecahan masalah siswa dengan pemberian soal esai sebanyak 5 nomer maka rata-rata nilai diperoleh 66,95 dengan kategori baik.
\end{abstract}

\section{Kata Kunci: Problem Solving, kemampuan pemecahan Masalah, Mata Pelajaran Ekonomi}

\begin{abstract}
Appropriate learning methods used in class will encourage students' learning enthusiasm. Students will not feel bored and students can be trained to think creatively. This study aims to determine how much influence the students' problem solving abilities have on economic subjects tax material using the problem solving method. This research was conducted at SMAN 1 Ciwidey, Bandung Regency. The subjects of this study were students of class XI majoring in Social Sciences (IPS) namely XI IPS 1 with a total of 34 students. The method to be used is quasiexperimental (quasi-experimental) to determine the treatment effect. Data analysis techniques using the validity and reliability test, normality test and hypothesis test. The results of the study concluded that the testing criteria were if Sig. (Significance) or probability value <0.05 then the distribution is not normal, whereas if the significance value or probability value> 0.05 then the distribution is normal. In problem solving abilities students use the problem solving method to obtain an average value of 79 before treatment with an average value of 27 with a KKM value of 70. In the determination of the indicators of students' problem solving abilities by giving essay questions by 5 numbers, the average value is 66, 95 with a good category.
\end{abstract}

Jurnal Edueksos Vol IX, No. 2, Desember 2020

The journal of social and economics education 


\section{Keywords: Problem Solving, Problem Solving Ability, Economic Subjects}

\section{A. PENDAHULUAN}

Pendidikan merupakan suatu proses yang diperlukan untuk mendapatkan keseimbangan dan kesempurnaan dalam perkembangan individu maupun masyarakat. Penekanan pendidikan dibanding dengan pengajaran yang terletak pada pembentukan kesadaran dan kepribadian individu atau masyarakat disamping transfer ilmu dan keahlian. Dengan proses semacam ini suatu bangsa atau Negara dapat mewariskan nilai-nilai keagamaan, kebudayaan, pemikiran dan keahlian kepada generasi berikutnya, sehingga mereka betul-betul siap untuk menyongsong ke masa depan kehidupan bangsa dan negara yang lebih cerah (Ayu Wardani et al., 2019).

Pasal 1 UU SISDIKNAS No. 20 Tahun 2003 disebutkan bahwa Sistem Pendidikan Nasional adalah keseluruhan komponen pendidikan yang saling terikat secara terpadu untuk mencapai tujuan pendidikan nasional. Berangkat dari bunyi pasal tersebut maka dapat diketahui bahwa Pendidikan adalah system yang merupakan suatu totalitas struktur yang terdiri dari komponen yang saling terkait dan secara bersama menuju kepada tercapinya tujuan. Adapun komponenkomponen (guru, kurikulum, sarana prasarana, lingkungan, peserta didik) tersebut bekerja secara bersama-sama, saling terkait dan mendukung dalam mencapai tujuan pendidikan (Ayu Wardani et al., 2019; Wijaya, 2020).

Perubahan paradigma pembelajaran dikelas yang menjadi tuntutan pendidik pada implementasi Kurikulum 2013 juga perlu untuk diperhatikan, sebagaimana yang dijelaskan oleh Kementrian Pendidikan dan Kebudayaan (2016) yaitu sebagai berikut:

1. Pembelajaran diarahkan untuk mendorong peserta didik mencari tahu dan bukan diberitahu dari berbagi sumber belajar yang tersedia dimana saja dan kapan saja melalui mengamati.

2. Pembelajaran diarahkan untuk mampu merumuskan masalah dengan melatih kemampuan bertanya, bukan hanya menyajikan dan memproses data dengan cepat dan tepat. 
3. Pembelajaran diarahkan untuk memotivasi peserta didik dan melatih berfikir analitis bukan berfikir mekanis.

4. Pembelajaran menekankan pentingnya kerjasama dan kolaborasi dalam menyelesaikan masalah, sehingga dapat mengomunikasikan informasi yang dihasilkan.

5. Pendidik diharapkan mampu merancang penilaian autentik yang mengarah pada berfikir tingkat tinggi.

Penjelasan tersebut menunjukkan bahwa, kemampuan pemecahan masalah yang merupakan salah satu aspek berfikir tingkat tinggi dinilai penting sehingga pendidik diharuskan melatih kemampuan bertanya siswa, agar mampu merumuskan masalah bukan hanya karena bantuan teknologi saja. Sejalan dengan penelitian Abbas dan Nurhayati (2016) mengemukakan pentingnya kemampuan pemecahan masalah diberikan kepada siswa, sehingga siswa mampu menyelesaikan masalah dalam pelajaran matematik dan juga ilmu pengetahuan lainnya serta untuk mampu memberikan kemampuan nalar yang logis, sistematis, kritis dan terbuka yang diperlukan dalam kehidupan sehari-hari.

Namun pada kenyataanmya, tingkat kemampuan pemecahan masalah masih sangat rendah. Hal tersebut dapat dilihat dari hasil survey The Trends in International Mathematics and Science Study (TIMSS) yang merupakan salah satu kegiatan dari the International Association for Evaluation of Internasional Achievement (IEA) pada tahun 2011 yang mengukur beberapa domain salah satunya adalah memecahkan masalah rutin. Dari 40 negara yang ikut serta, prestasi Indoensia dalam matematika berada diurutan ke-36 dengan skor rata-rata 386. Secara umum, hasil tersebut menunjukkan bahwa siswa mempunyai pengetahuan dasar matematika akan tetapi tidak cukup untuk memecahkan masalah rutin dan non rutin (Tjalla dkk, 2009).

Serupa dengan keadaan siswa di SMA Negeri 1 Ciwidey. Berdasarkan hasil wawancara dengan salah satu guru mata pelajaran ekonomi menyatakan bahwa kebanyakan siswa kurang mampu menyelesaikan soal pada perhitungan. Hal ini ditandai hasil ulangan harian siswa dibawah KKM (Kriteria Ketuntasan Minimal), 
sedangkan KKM unutk mata pelajaran ekonomi tahun pelajaran 2019/2020 di SMA Negeri 1 Ciwidey adalah 75.

Tabel 1 Rata-Rata Ketuntasan Ulangan Harian Pokok Bahasan Pendapatan Nasional Kelas XI SMAN 1 Ciwidey Tahun Ajaran 2019/2020

\begin{tabular}{|c|c|c|c|c|c|c|}
\hline \multirow{2}{*}{ Kelas } & \multirow{2}{*}{$\begin{array}{l}\text { Jumlah } \\
\text { Siswa }\end{array}$} & \multirow{2}{*}{$\begin{array}{l}\text { Rata-rata } \\
\text { Nilai }\end{array}$} & \multicolumn{2}{|c|}{ Belum Tuntas } & \multicolumn{2}{|c|}{ Tuntas } \\
\hline & & & $<75$ & $\%$ & $<75$ & $\%$ \\
\hline XI-IIS 1 & 34 & 74,25 & 10 & 29,41 & 24 & 70,59 \\
\hline XI-IIS 2 & 33 & 77,20 & 12 & 36,36 & 21 & 63,64 \\
\hline XI-IIS 3 & 34 & 75,65 & 8 & 23,53 & 26 & 76,47 \\
\hline XI-IIS 4 & 36 & 72,20 & 8 & 22,22 & 28 & 77,78 \\
\hline XI-IIS 5 & 34 & 78,80 & 9 & 26,47 & 25 & 73,53 \\
\hline XI-IIS 6 & 33 & 72,32 & 11 & 33,33 & 22 & 66,67 \\
\hline
\end{tabular}

Sumber : Data Penelitian

Soal yang tidak dapat diselesaikan oleh seorang siswa tentunya menjadi masalah baginya tetapi belum tentu menjadi masalah bagi siswa yang lain, karena suatu soal akan menjadi masalah bagi seseorang ketika ia tidak memiliki aturan atau cara yang segera dapat digunakan untuk menyelesaikan soal tersebut. Sehingga dapat dikatakan bahwa masalah itu merupakan soal belum tentu merupakan masalah.

Berkaitan dengan Tabel 1, penyebab rendahnya pencapaian siswa SMAN 1 Ciwidey kelas XI IPS pada mata pelajaran ekonomi dalam mencapai nilai KKM hasil wawancara dengan guru adalah:

1. Sebagian besar siswa tidak bisa mengindentifikasi apa yang diketahui dan yang ditanya pada soal.

2. Sebagian besar siswa tidak bisa memilih data dan informasi yang relevan dalam memecahkan masalah.

3. Sebagian besar siswa salah dalam mengidentifikasikan perhitungan pajak. 
4. Sebagian besar siswa tidak bisa memilih prosedur yang tepat terhadap permasalahan yang ada.

5. Pada akhir pembelajaran sebagian siswa belum bisa mengambil kesimpulan terhadap apa yang dipelajari.

Berdasarakan permasalahan-permasalahan diatas maka ada sebuah solusi untuk dapat meningkatkan kemampuan pemecahan masalah siswa tersebut. Salah satu metode pembelajaran yang dapat digunakan untuk meningkatkan kemampuan pemecahan masalah adalah metode pembelajaran problem solving. Problem solving adalah belajar memecahkan masalah berdasarkan beberapa prinsip atau gejala atau peristiwa yang telah terjadi dengan beberapa kemungkinan. Pada tingkat ini siswa belajar untuk merumuskan dan memecahkan masalah, serta memberikan respon terhadap rangsangan yang menggambarkan atau membangkitkan situasi problematik dengan menggunakan berbagai kaidah yang telah dikuasinya (Mufarokah, 2009).

Teori belajar yang mendasari problem solving yaitu teori pembelajaran konstruktivisme. Penegatahuan tidak diperoleh seacara pasif oleh seseorang melainkan melalui tindakan. Bahkan, perkembangan kognitif anak tergantung pada seberapa jauh mereka aktif memanipulasi dan berinteraksi dengan lingkungannya.

Metode problem solving ialah cara mengajar dengan memotivasi siswa selaku peserta didik berpikir ke depan, serta menganalisa persoalan yang terjadi dan kemuadian berusaha untuk memberikan solusi dari permasalahan yang ada. Problem solving merupakan sebuah metode pembelajaran yang bertujuan agar siswa lebih aktif dalam berpikir, karena metode ini terfokus pada keterapilan siswa untuk menyelesaikan masalah yang dihadapi (Hidayat, n.d.).

Dewey menyatakan bahwa terdapat beberapa tahapan yang harus dilakukan untuk mendapatkan hasil yang maksimal dalam proses pembelajaran problem solving yaitu dimulai dari merumuskan masalah sampai dengan merumuskan rekomendasi solusi terhadap permasalahn yang terjadi (Nasution, 2008: 171). Berdasarkan pendapat tersebut dapat dibuat tahapan secara lengkap yaitu: 
1. Merumuskan masalah, yaitu langkah siswa menentukan masalah yang akan dipecahkan atau masalah tersebut diberikan oleh guru untuk diselesaikan.

2. Menganalisis masalah, yaitu langkah siswa meninjau masalah secara kritis dan dinamis dari berbagai sudut pandang.

3. Merumuskan hipotesis, yaitu langkah siswa merumuskan berbagai kemungkinan pemecahan atau solusi sesuai dengan pengetahuan yang dimilikinya.

4. Mengumpulkan data, yaitu langkah siswa mencari dan menggambarkan informasi yang diperlukan untuk pemecahan masalah.

5. Pengujian hipoteis, yaitu langkah siswa mengambil atau merumuskan kesimpulan sesuai dengan penerimaan dan penolakan hipotesis yang diajukan.

6. Merumuskan rekomendasi pemecahan masalah, yaitu langkah siswa menggambarkan solusi yang akan dilaksanakan untuk pemecahan masalah.

Semua metode yang dilakukan dalam proses pembelajaran, tentunya mempunyai kelebihan maupun kekurangan. Adapun kelebihan dari penerapan metode problem solving ialah :

1. Dapat membuat siswa menjadi lebih menghayati kehidupan sehari-hari.

2. Dapat melatih dan membiasakan para siswa untuk menghadapi dan memecahkan masalah secara terampil.

3. Dapat mengenmbangkan kemampuan berpikir siswa secara kreatif.

4. Siswa sudah mulai dilatih untuk memecahkan masalahnya.

5. Mendorong siswa untuk berpikir ilmiah, kritis, dinamis serta objektif menghadapi masalah yang berbeda.

Sedangkan kekurangan dari metode problem solving ialah :

1. Memerlukan cukup banyak waktu.

2. Melibatkan labih banyak orang.

3. Dapat mengubah kebiasaan siswa belajar dengan mendengarkan dan menerima informasi dari guru.

Kemampuan pemecahan masalah jika dapat dilihat dari sudut pandang psikologi merupakan bagian dari teori pemerosesan informasi. Menurut teori ini ada tiga komponen penting yang terlibat dalam pemecahan masalah yaitu content 
knowledge, working memory, dan long term memory (Maliki dkk, 2016). Content knowledge adalah komponen yang menentukan seseorang dapat memecahkan suatu permasalahan, jika dianalogikan maka content knowledge adalah bahan dasar yang dapat digunakan untuk memecahkan suatu permasalahan, sedangkan long term memory adalah tempat disimpannya content knowledge, dan working memory adalah tempat diprosesnya suatu informasi (termasuk content knowledge) untutk memecahkan suatu permasalahan.

Kemampuan pemecahan masalah dapat dilihat dari stategi umum yang digunakan dalam memecahkan masalah. Ada beberapa pendapat terkait strategi umum yang digunakan dalam memecahkan masalah, diantarnya adalah Polya (1957), Heller (1992), Reif (1995) dan Docktor (2009). Polya (Ifanali, 2014) mengartikan bahwa pemecahan masalah sebagai usaha mencari jalan keluar dari suatu kesulitan, dan untuk mencapai suatu tujuan yang tidak dengan segera dapat dicapai. Lebih lanjut dijelaskan bahwa pemecahan masalah merupakan suatu tingkat aktivitas intelektual yang sangat tinggi. Hal ini sejalan dengan yang dikemukakan oleh Gagne (Ifanali, 2014) bahwa keterampilan intelektual tinggi perlu dikembnagkan melalui pemecaha masalah.

Teori yang mendukung langkah-langkah Polya adalah teori Ausubel, yang mengemukakan bahwa menerima dan menemukan adalah langkah pertama dalam belajar. Langkah kedua adalah usaha mengingat atau menguasai apa yang dipelajari agar kemudian dapat dipergunakan (Ifanali, 2014). Tahapan strategi penyelesaian masalah yang telah dikenalkan oleh (Maliki dkk, 2016) ialah (1) Visualize the problem (2) Physics description, (3) Plan a solution, (4) Execute the plan, (5) Check and evaluate.

Kemampuan pemecahan masalah menurut Heller \& Reif dikutip oleh (Pembelajaran Melalui Kegiatan Laboratorium dkk, 2013) merupakan penyidikan tugas dengan jalan pemecah masalah menggali atau mengeksplorasi solusi untuk mencari konsep dari suatu informasi yang diberikan. Dalam memecahkan masalah dapat dilakukan dengan metode ilmiah, metode ilmiah, metode ilmiah menurut (Pembelajaran Melalui Kegiatan Laboratorium dkk, 2013) meliputi : memahami masalah, merumuskan hipotesis, mengumpulakn bukti atau data, mencapai 
kesimpulan, menemukan konsep. Maka dapat disimpulkan bahwa kemampuan pemecahan masalah merupakan keterampilan dalam menyelesaikan persoalan contohnya siswa dapat memecahkan dan menyelesaikan soal yang diberikan oleh guru.

Terdapat lima tahap dalam memecahkan masalah (Safrina dkk, 2014) sebagai berikut:

1. Membaca (read), aktifitas yang dilakukan siswa pada tahap ini adalah mencatat kata kunci, bertanya kepada siswa lain apa yang sedang ditanyakan pada masalah, atau menyatakan kembali masalah kedalam bahasa yang lebih mudah dipahami.

2. Mengeksplorasi (explore), proses ini meliputi pencarian pola untuk menentukan konsep atau prinsip dari masalah. Pada tahap ini siswa mengidentifikasi masalah yang diberikan, menyajikan masalah kedalam cara yang mudah dipahami. Pertanyaan yang digunakan pada tahap ini adalah, "seperti apa masalah tersebut"?

3. Memilih suatu strategi (select a strategy), pada tahap ini siswa menarik kesimpulan atau membuat hipotesis mengenai bagaimana cara menyelesaikan masalah yang ditemui berdasarkan apa yang sudah diperoleh pada tahap dua dan pertama.

4. Menyelesaikan masalah (solve the problem), pada tahap ini semua keterampilan metematika seperti menghitung dilakukan untuk menemukan suatu jawaban.

5. Meninjau kembali dan mendiskusikan (review and extend), pada tahap ini siswa mengecek kembali jawabannya dan melihat variasi dari cara memecahkan masalah. 


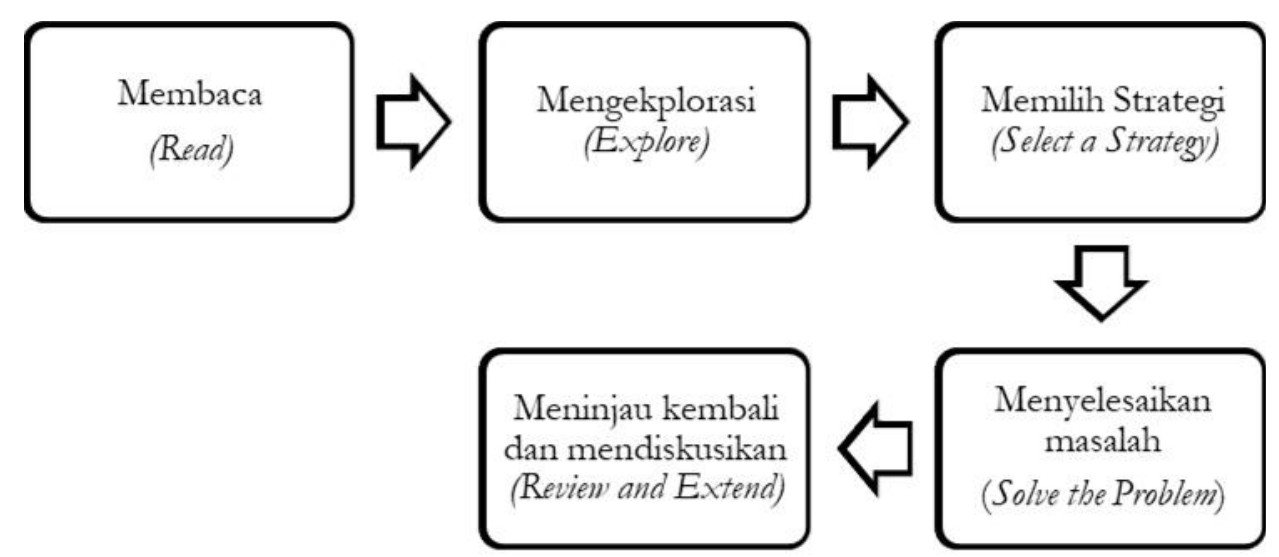

\section{Gambar 1 Tahap Kemampuan Pemecahan Masalah Kemapuan Pemecahan Masalah}

\section{B. METODE PENELITIAN}

Penelitian ini menggunakan eksperimen semu (quasi ekperiment) untuk menegetahui efek perlakuan (treatment). Alat yang digunakan dalam penelitian ini yaitu tes. Prosedur penelitian dalam mengumpulkan data dilakukan sebagai berikut:

1. Tahap studi pendahuluan

2. Tahap pemilihan subjek penilitan

3. Tahap pembuatan alat penelitian tes

4. Tahap uji coba dan perbaikan alat penelitian

5. Melakukan pre test

6. Pemberian perlakuan (treatment)

7. Pemberian post tes

8. Pengolahan dan analisis data hasil penelitian

9. Interpretasi hasil dan pembahasan

10. Penarikan kesimpulan penelitian dan saran

Penelitian dilakukan di SMAN 1 Ciwidey Kabupaten Bandung. Subjek dalam penelitian ini yaitu kelas XI IPS 1 berjumlah 34 siswa dijadikan kelas eksperimen dengan penerapkan metode problem solving. Pendekatan penelitian ini yaitu menggunakan pendekatan kuantitatif. 
Untuk mendapatkan data yang mendukung penelitian, maka penelitian ini menyusun dan menyiapkan beberapa instrumen untuk menjawab penelitian. Tes diberikan pada kelas eksperimen yaitu kelas XI IPS 1 sebagai tes akhir (post test) untuk mengetahui kompetensi yang telah diajarkan.

Instrumen yang digunakan dalam tes akhir yang berupa soal essai. Penyusunan tes diawali dengan pembuatan kisi-kisi soal, kemudian dilanjutkan pada penyusunan soal, kunci jawaban dan aturan pemberian skor untuk masing-masing soal. Berikut pedoman penskoran kemampuan pemecahan masalah yang diadopsi dari (Excaferina, 2014).

Tabel 2 Pedoman Penskoran Kemampuan Pemecahan Masalah

\begin{tabular}{|l|c|}
\hline \multicolumn{1}{|c|}{ Respon Siswa Terhadap Soal atau Masalah } & Skor \\
\hline Tidak menjawab & 0 \\
\hline Terdapat kesalahan dalam jawaban dan tidak disertai perincian & 4 \\
\hline Terdapat kesalahan dalam jawaban tapi disertai perincian & 10 \\
\hline Memberi jawaban yang mendekati benar dan rinci & 15 \\
\hline Memberi jawaban yang benar dan rinci & 20 \\
\hline \multicolumn{2}{|c|}{ Skor Maksimum $=20$} \\
\hline
\end{tabular}

Teknik analisis data berupa uji Validitas. Validitas adalah suatu ukuran yang menunjukkan tingkat-tingkat kevalidan suatu instrumen (Arikunto, 2010). sebelum tes digunakan sebagai alat pengumpulan data, terlebih dahulu tes diuji coba dengan analisis valisitas. Instrumen tes berbentuk essai sebanyak 5 soal. Pengujian validitas instrumen tes dilakukan menggunakan aplikasi SPSS 23. Setelah instrumen dinyatakan telah valid, maka langkah selanjutnya menguji 
reliabilitasnya. Pengujian reliabilitas insterumen tes dilakukan menggunkan aplikasi SPSS 23.

Uji normalitas digunakan untuk mengetahui normal atau tidaknya distribsui data. Pengujian pada uji normalitas data menggunakan uji Kolmogorov Smirnov dengan menggunakan bantuan software computer SPSS versi 23. Kriteria pengujiannya adalah jika Sig. (Signifikansi) atau nilai probabilitas $<0,05$ maka distribusi adalah tidak normal, sedangkan jika nilai signifikansi atau nilai probabilitas > 0.05 maka distribusi adalah normal.

Perhitugan hipotesis penelitian menggunakan uji ANOVA dengan bantuan software komputer SPSS versi 23. Kriteria pengujiannya adalah:

1. Jika nilai sig (signifikansi) atau nilai probabilitas $<0,05$ maka hipotesis penelitian yang di ajukan $\mathrm{H}_{\mathrm{A}}$ diterima dan $\mathrm{H}_{0}$ ditolak.

2. Jika nilai sig (signifikansi) atau nilai probabilitas $>0,05$ maka hipotesis penelitian yang diajukan $\mathrm{H}_{\mathrm{A}}$ ditolak dan $\mathrm{H}_{0}$ diterima.

Adapun hipotesis statistic penelitian adalah sebagai berikut:

1. Tidak terdapat pengaruh kemampuan pemecahan masalah siswa yang menggunakan metode problem solving.

2. Terdapat pengaruh kemampuan pemecahan masalah siswa yang menggunakan metode problem solving.

\section{HASIL DAN PEMBAHASAN}

1. Hasil Penelitian

a. Kemampuan Pemecahan Masalah Siswa Menggunakan Metode Problem Solving

Kemampuan memecahkan masalah pada penelitian ini melibatkan satu kelas yaitu kelas eksperimen di kelas XI IPS 1 dengan menggunakan metode problem posing. Untuk setiap kelasnya diberikan pertemuan sebanyak 4 kali, untuk mengukur kemampuan pemecahan masalah. Diakhir pertemuan, untuk mengukur kemampuan pemecahan masalah peneliti menggunakan instrumen tes yang disesuaikan dengan indikator 
memecahkan masalah dan alat tes diberikan berupa soal essai sebanyak 5 soal.

Berdasarkan hasil tes tersebut diperoleh skor tes kemampuan pemecahan masalah yang dapat dilihat dari data perolehan pre test dan post test siswa. Untuk dapat melihat perbedaan nilai kemampuan pemecahan masalah siswa dapat dilihat dari rata-rata pre test dan post test yang terdapat dalam diagram di bawah ini:

\section{Gambar 2 Perbedaan Rata-rata Nilai Pre Test dan Post Test Kemampuan Pemecahan masalah}

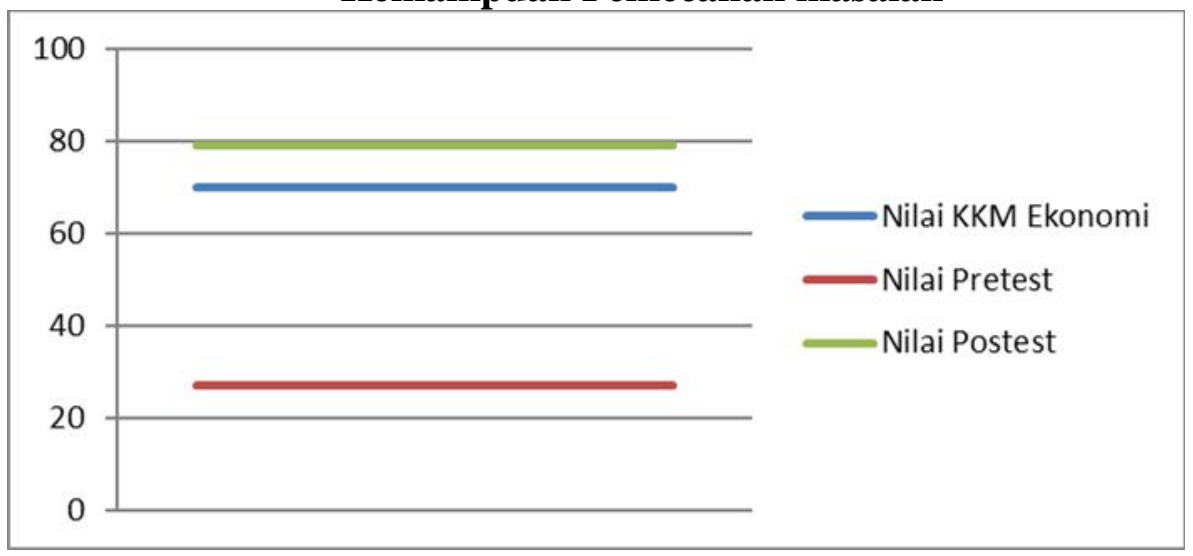

Berdasarkan Gambar 2, diagram menunjukkan nilai rata-rata pre test dan post test di SMAN 1 Ciwidey. Dimana nilai rata-rata kemampuan pemecahan masalah siswa sebelum perlakuan (treatment) yaitu pada pre test memiliki rata-rata 27 , sedangkan setelah diberikan treatment problem solving rata-rata post test sebesar 79. Ini berarti terdapat selisih skor 52 lebih tinggi rata-rata setelah diberikan perlakuan metode problem solving dibandingkan sebelum diberi perlakuan.

b. Ketuntasan Indikator Kemampuan Pemecahan Masalah Siswa SMAN 1 Ciwidey

Kemampuan memecahkan masalash siswa secara keseluruhan setelah diberikan treatment menggunakan metode problem solving, terlihat pada Tabel 3 berikut. 
Tabel 3. Rata-Rata Hasil Tes Kemampuan Pemecahan Masalah Siswa Pada Materi Pendapatan Nasional Siswa Kelas XI IIS SMAN 1 Ciwidey Tahun Ajaran 2019/2020

\begin{tabular}{clcc}
\hline No. & \multicolumn{1}{c}{$\begin{array}{c}\text { Indikator Kemampuan } \\
\text { Pemecahan Masalah }\end{array}$} & $\begin{array}{c}\text { Rata-Rata Nilai } \\
\text { Setiap Indikator }\end{array}$ & Kriteria \\
\hline 1 & Membaca (Read) & 72,00 & Baik \\
\hline 2 & Mengekplorasi (Explore) & 70,50 & Baik \\
\hline 3 & $\begin{array}{l}\text { Memiloh Strategi (Select a } \\
\text { Strategy) }\end{array}$ & 67,00 & Baik \\
\hline 4 & $\begin{array}{l}\text { Menyelesaikan masalah (Solve } \\
\text { the Problem) }\end{array}$ & 63,00 & Cukup \\
\hline 5 & $\begin{array}{l}\text { Meninjau kembali dan } \\
\text { Mendiskusikan (Review and } \\
\text { Extend) }\end{array}$ & 62,25 & Cukup \\
\hline \multicolumn{1}{c}{ Rata-Rata } & 66,95 & Baik \\
\hline
\end{tabular}

\section{Sumber: Penelitian}

Dari Tabel 3 diperoleh data bahwa rata-rata kemampuan pemecahan per indikator dan diperoleh jumlah rata-rata sebesar 93,30 dalam kriteria baik sekali.

\section{KESIMPULAN}

Pengaruh metode pembelajaran problem solving yang diterapkan pada kelas XI IPS 1 di SMAN 1 Ciwidey dapat disimpulkan bahwa siswa antusias dalam kegiatan pembelajaran dengan menggunakan metode tersebut. Prosedur penelitian dalam mengumpulkan data dilakukan dengan tahap studi pendahuluan, tahap pemilihan subjek penilitam, tahap pembuatan alat penelitian tes, tahap uji coba dan perbaikan alat penelitian, melakukan pre test, pemberian perlakuan (treatment), pemberian post tes, pengolahan dan analisis data hasil penelitian, interpretasi hasil dan pembahasan dan penarikan kesimpulan penelitian dan saran.

Uji normalitas digunakan untuk mengetahui normal atau tidaknya distribsui data. Pengujian normalitas data menggunakan uji Kolmogorov Smirnov, menggunakan bantuan software komputer SPSS versi 23. Kriteria pengujiannya adalah jika Sig. (Signifikansi) atau nilai probabilitas $<0,05$ maka distribusi adalah tidak normal, sedangkan jika nilai signifikansi atau nilai probabilitas $>0.05$ maka distribusi adalah normal. Diperoleh nilai rata-rata kemampuan pemecahan 
masalah siswa sebelum perlakuan (treatment) yaitu pada pre test memiliki ratarata 27 , sedangkan setelah diberikan treatment problem solving rata-rata post test sebesar 79. Ini berarti terdapat selisih skor 52 lebih tinggi rata-rata setelah diberikan perlakuan metode problem solving dibandingkan sebelum diberi perlakuan.

Berdasarkan kesimpulan dari hasil penelitian, maka disarankan bagi para guru ekonomi agar menngunakan metode problem solving dalam meningkatkan kemampuan pemecahan siswa dalam pembelajaran ekonomi pada materi pajak karena pada SMAN 1 Ciwidey rata-rata kemampuan pemecahan per indikator dan diperoleh jumlah rata-rata sebesar 93,30 dalam kriteria baik sekali.

\section{DAFTAR PUSTAKA}

Arikunto, S. 2010. Prosedur Penelitian Suatu Pendekatan Praktik. Jakarta: Rineka Cipta.

Ayu Wardani, N. M., Suniasih, N. W., \& Sujana, N. W. (2019). Korelasi Antara Konsep Diri dengan Kemampuan Pemecahan Masalah IPS. Thinking Skills and Creativity Journal, 2(1), 37. https://doi.org/10.23887/tscj.v2i1.18382

Depdiknas. (2003). Undang-undang RI No.20 tahun 2003.tentang sistem pendidikan nasional.

Hidayat, K. (n.d.). Ekonomi Menggunakan Metode Problem Solving Dengan Metode Ceramah Diskusi Di Sma Muhammadiyah.

Ifanali. (2014). Soal Cerita Pecahan Pada Siswa Kelas Vii. Jurnal Elektronik Pendidikan Matematika Tadulako, 01(Maret), 147-158. http://jurnal.untad.ac.id/jurnal/index.php/JEPMT/article/view/3217

Maliki, I. M. A. M., Hidayat, A., \& Rukmijati. (2016). Identifikasi Kemampuan Pemecahan Masalah Siswa Kelas X Sman 9 Malang Pada Topik Suhu Dan Kalor. Jurnal.Unej.Ac.Id, 1(1995), 801-807. https://jurnal.unej.ac.id/index.php/JPF/article/view/3726

Mufarokah, Anissatul. 2009. Strategi Belajar Mengajar. Yogyakarta: Teras.

Nasution. (2008). Berbagai pendekatan dalam proses belajar mengajar. Jakarta: PT. Bumi Aksara

Pembelajaran Melalui Kegiatan Laboratorium, P., Usrotin, D., Eko Nugroho Jurusan Fisika, S., \& Matematika dan Ilmu Pengetahuan, F. (2013). UPEJ 2 (3) (2013) Unnes Physics Education Journal. 2(3). 
Safrina, K., Ikhsan, M., \& Ahmad, A. (2014). Peningkatan kemampuan pemecahan masalah geometri melalui pembelajaran kooperatif berbasis teori van hiele. Jurnal Didaktik Matematika.

Utami, Excaferina. (2016). Pengaruh Metode Guided Discovery Learning Terhadap Kemampuan Pemecahan Masalah Dengan Variabel Moderator Kemandirian Belajar Siswa. Tesis Universitas Pendidikan Indonesia (tidak diterbitkan).

Wijaya, A. K. (2020). Integrasi Model Role Playing dengan Multimedia terhadap Keterampilan Partisipsi Sosial Siswa. Edueksos : Jurnal Pendidikan Sosial dan Ekonomi. Volume 9 (1). 98-113. DOI: 10.24235/edueksos.v9i1.6420. https://www.syekhnurjati.ac.id/jurnal/index.php/edueksos/article/view/6420 